\title{
New Pre-Pottery Neolithic sites and cult centres in the Urfa Region
}

\author{
Gül Güler ', Bahattin Çelik ${ }^{2}$ and Mustafa Güler 3 \\ 1 Department of Islamic History and Arts, University of Harran, Şanlıurfa, TR \\ gulguler67@hotmail.com \\ 2 Department of Archaeology, University of Harran, Şanlıurfa, TR \\ bcelik@harran.edu.tr \\ 3 Department of Architecture, University of Harran, Şanlıurfa, TR \\ mguler63@hotmail.com
}

\begin{abstract}
The present study assesses the sites and the corresponding artefacts that were recently discovered during cultural inventory studies in the Urfa region in south-eastern Turkey. The studies were conducted at PPN sites located at Herzo Tepe, Başaran Höyük and Kocanizam, Taşl Tepe and Inanl Tepe within the borders of Viransehir and Siverek boroughs; the already known site at Sefer Tepe is also re-examined. The sites extend in a north-south direction and were founded within a 3-5km distance, and they exhibit unique characteristics for this region. Recently discovered sites are compared to already known PPN sites in the region to reveal similar features and characteristics. In particular, the article elaborates similarities and discrepancies between sites with T-shaped pillars and sites with circular structures. The recently discovered sites demonstrate that the pillar tradition is predominant in the region and that the settlements have a distinct layout.
\end{abstract}

IZVLEČEK - V študiji ovrednotimo najdišča in pripadajoče artefakte, ki so bili nedavno odkriti pri študijah kulturnih inventarjev v regiji Urfa na območju južno-vzhodne Turčije. Analize so bile opravljene na najdiščih predkeramičnega neolitika na območjih kot so Herzo Tepe, Başaran Höyük in Kocanizam, Taşh Tepe in Inanl Tepe znotraj mestnih okrajev Viranşehir in Siverek; ponovno smo preiskali tudi že znano najdišče Sefer Tepe. Najdišča se raztezajo v smeri sever-jug in so postavljena $v$ razdalji od 3 do 5km, poleg tega pa izkazujejo edinstvene značilnosti za to območje. Nedavno odkrita najdišča primerjamo z že znanimi predkeramičnimi najdišči v regiji in na ta način ugotavljamo njihove podobnosti in značilnosti. V članku se podrobneje ukvarjamo s podobnostmi in razlikami med najdišči s stebri $v$ obliki črke T in najdišči s krožnimi strukturami. Nedavno odkrita najdišča kažejo, da v tej regiji prevladuje tradicija stebrov in da imajo naselbine značilne prostorske ureditve.

KEY WORDS - Pre-Pottery Neolithic; T-shaped pillar; circular structures; Siverek; Viranşehir

\section{Introduction}

Herzo Tepe, Başaran Höyük, Kocanizam Tepe, Sefer Tepe, Taşlı Tepe and İnanlı Tepe sites (Map 1), which are being investigated in the Sanliurfa Province Cultural Inventory studies since 2011, are located within the borders of Şanliurfa Province in southeastern Turkey. All sites are located within borders of today's Viranşehir and Siverek boroughs of Şanlıurfa (Urfa) Province.
The recently discovered sites extend in a north-south direction and were founded within a distance of 3$5 \mathrm{~km}$. Tools made from flint stone and obsidian were discovered during the field survey at these sites. The archaeological material from the sites features finds dating to the Pre-Pottery Neolithic Period. T-shaped pillars, known from locations such as Nevali Çori, Göbekli Tepe, Sefer Tepe and Hamzan Tepe, were 
also discovered at some of the sites. Moreover, architectural remains with a circular layout are also encountered at some sites. The other characteristics of these sites will be elaborated in this article according to the region where they were discovered.

\section{Neolithic in Siverek region}

Siverek is located in the borough in the north-eastern part of Şanliurfa province. Karacadağ, the only dormant volcanic mountain in Sanliurfa, with an altitude of $1938 \mathrm{~m}$, is located on the northeast border of the region. The geological formation of the mountain is dominated by basaltic rocks in the north, while the southern and south-western sections are made of calcareous rocks. The southern and southwestern areas are in the form of plains and low plateaus.

Areas with water sources cover large parts of the Siverek region compared to other regions in Şanliurfa province. Water sources arising from Karacadağ flow to the Habur stream in a north-south direction. The southern side of Karacadağ and the northern sections of the region have an abundance of water sources. The period of drought starts in Siverek region in the middle of the summer and encompass fields serving as pastureland. In general, the Siverek region is on average $3^{\circ} \mathrm{C}$ cooler than the Sanlıurfa city center.

No inventory studies have been conducted in the region, but are currently in progress in the region at the sites of Taşl Tepe (Celik et al. 2011b.225-236) and İnanlı Tepe dating to the Pre-Pottery Neolithic period that were discovered during the studies since 2011. The site at İnanlı Tepe will be presented for the first time in the present article (Map 1).

\section{Taşlı Tepe}

The Taşl Tepe site is located in the north-eastern part of the Şanliurfa Province (Celik et al. 2011). Located $c .740 \mathrm{~m}$ above sea level, the site covers a surface area of $c .12000 \mathrm{~m}^{2}$ (Map 1). The site extends $c .4 \mathrm{~m}$ above the bedrock. Today, this location is used for agriculture (Fig. 1). Two dry stream beds extend in an east-west direction $c .300 \mathrm{~m}$ to the north and $250 \mathrm{~m}$ to the south of the site. The examination of the geological structure revealed that the region is formed by calcareous and basalt platforms. The closest source of basalt to the site is $2 \mathrm{~km}$ to the south. Flint stone outcrops are encountered $2 \mathrm{~km}$ southeast of the site. High plateaus with heights varying from 800 up to $850 \mathrm{~m}$ are present in the southwest, east and north of Tassli Tepe. The southern and western sides of the site, on the other hand, extend as partially plain terrain.

The Taşl 1 Tepe site was inhabited only during the Pre-Pottery Neolithic period. The archaeological finds have been divided into two categories: architectural elements and small finds. Accordingly, the small finds might be listed as tools made of flint stone, small flat axes made of river pebbles, stone beads, stoneware pottery pieces, grind stones and pestles. The finds comprise 6 small finds and 7 architectural elements. All the architectural elements are pieces of a T-shaped pillar. As a result of the examinations of the flint stone finds and architectural elements discovered at the site, it is understood that Taşlı Tepe settlement site was used as a cult centre during the Pre-Pottery Neolithic period.

\section{Pre-Pottery Neolithic assemblage in Taşl Tepe} Architectural elements. The architectural remains at Taşlı Tepe were destroyed by agricultural activity. However, during an excavation carried out on the south-eastern slope of the site, fragments of T-shaped pillars were found in an area of $7 \times 8 \mathrm{~m}$ and $1 \mathrm{~m}$ deep. All pillars are made of limestone. One of the fragmented pillars has been restored and reassembled; its apparent length is $152 \mathrm{~cm}$; the width of the capital section is $93 \mathrm{~cm}$, while the thickness is $22 \mathrm{~cm}$ (Fig. 2). The dimensions of the T-shaped pillar pieces discovered at Tasslı Tepe site demonstrate a significant similarity with the Level II pillars at Göbekli Tepe (Schmidt 2002.8, Fig. 7) ${ }^{\mathbf{1}}$, the pillars of the temple building at Nevali Cori (Hauptmann 1991/ 1992.28, Abb. 21), and in-situ pillars located on the surface of Karahan Tepe (Celik 2000b.6-7, Fig. 1) and Sefer Tepe (Celik 2006a.23-25, Fig. 2). The Taşl1 Tepe pillars had no preserved relief or engravings. A fragment of terrazzo floor was also discovered from the same excavation site (Fig. 3). Similar terrazzo floors were also discovered in Göbekli Tepe, Nevali Çori and the Şanlıurfa-Yeni Mahalle mound unearthed in the region (Celik 2007.Fig. 16; Hauptmann 2007.142, Fig. 7-8a-b).

Small finds. A total of 16 small finds were collected from the Taşl Tepe site. The finds comprise 7 flint tools (Fig. 4. 1-7), 1 small flat axe made of river pebble (Fig. 4.9) and 1 stone bead (Fig. 4.8). The other finds are 2 basalt pestles, 1 stone dish (Fig. 5), 3 upper parts of a grind stone and 1 lower part of a grind stone (Fig. 6), respectively. Flint finds are com-

1 Pillars at L10-71, L9-80, L9-55 and L9-56 trenches. 


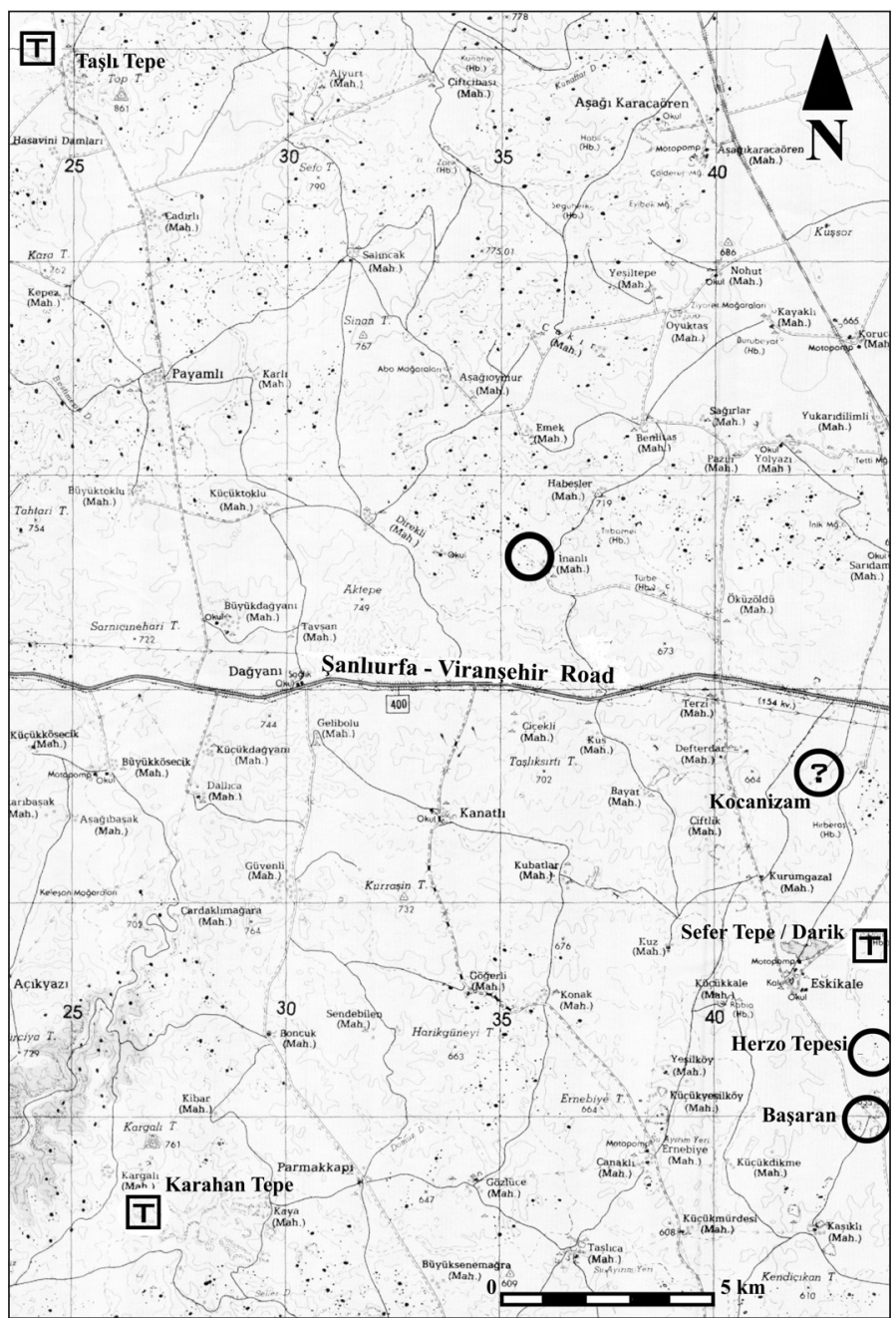

Map 1. Pre-Pottery Neolithic Period sites in Viranşehir and Siverek boroughs.

mon in the entire area. The number of flint tools discovered is around 12 per $\mathrm{m}^{2}$.

The small finds at Taşlı Tepe are mostly flint and a small number of obsidian tools. The majority of the flint and obsidian tools are blades. High-quality flint stones were used as raw materials and the nearest flint deposits were found $2 \mathrm{~km}$ southeast of the site. The flint tool assemblage comprises 4 arrowheads (Fig. 4.4-7) and 1 round end scraper (Fig. 4.3). Only one core was discovered at Taşl Tepe, i.e. a naviform core, which appears to be bipolar (Fig. 4.1). Moreover, 1 piece of crested blade was also unearthed as a core renewal piece (Fig. 4.2). An examination of the colour distribution of all flint finds revealed 3 dark gray and 4 light and dark brown colours. The blade flaking of the bipolar cores varies from 1 to $1.5 \mathrm{~cm}$. One core is grey; cores of similar colour were also found at Göbekli Tepe (Beile-Bohn et al. 1998.54) and Nevali Çori (Schmidt 1988.162).

One intact flint arrowhead appears to be of the Byblos type (Fig. 4.4). Similar specimens of were found at Göbekli Tepe (Schmidt 1988.Fig. 8; 2001.52, Fig. 10/3-11/5; BeileBohn et al. 1998.Abb. 23.3), Sanliurfa-Yeni Mahalle (Celik 2000a.Fig. 5.1; 2007.Fig. 20/6) and Karahan Tepe (Celik 2011b.Fig. 18.1 type I). Typologically, the types of tools from the Pre-Pottery Neolithic Period are observed when the flint tools are examined as a whole. The single shallow stone dish, which was discovered at Taşl Tepe, is an interesting find since similar stone dishes were encountered in Level II at Göbekli Tepe (Schmidt 2007.Catalogue 129) and as a grave good at Körtik Tepe (Özkaya, Coşkun 2007.86-88, Catalogue 144). Another extraordinary artefact discovered at the site is a bead made of green river pebbles in the form of a bull's head (Fig. 4.8). Similar beads were found at Köşk Höyük from the Late Neolithic period (Öztan 2012. Fig. 18b) ${ }^{2}$.

The T-shaped pillars discovered at Taşlı Tepe greatly resemble the pillars discovered at Sefer Tepe, Karahan Tepe and Level II of Göbekli Tepe with respect to their dimensions. In the light of all these artefacts, Taşl Tepe appears to be contemporaneous with the excavated sites at Göbekli Tepe (Level II) and at Nevalı Cori (Level III). Therefore, we can date the Taşlı Tepe site into the early PPNB period.

\section{İnanlı Tepe}

Innanlı Tepe is located $c .697 \mathrm{~m}$ above sea level in the northern end of the İnanlı village, $64 \mathrm{~km}$ east of Ur$\mathrm{fa}, 80 \mathrm{~km}$ south of Siverek and $c$. $12 \mathrm{~km}$ north of Sefer Tepe (Map 1). Founded on a calcareous hill, the site covers an area of $c .15000 \mathrm{~m}^{2}$. The mound soil extends $c .2 \mathrm{~m}$ high, starting from the bedrock. The site is comprised of two small, low hills presenting an ample structure (Fig. 7). The area, on which the site was founded, is currently used as pasture. A dried stream bed is located $700 \mathrm{~m}$ to the south. The geological structure of the region is formed by calcareous plateaus. Such plateaus present an extremely low and frequent structure. The closest source

2 The red coloured bead at the middle is the bead with the shape of bull's head. 
of basalt is $c$. $5 \mathrm{~km}$ northwest of the site. Plain areas are present to the east and southeast, $7 \mathrm{~km}$ from the site.

Flint stone artefacts could be collected over the entire area at Inanlı Tepe; the number of flint tools discovered is $c .7$ per $\mathrm{m}^{2}$ area. The results of the examinations on flint tools and architectural elements discovered at the site show that Inanlı Tepe was used as a settlement during the Pre-Pottery Neolithic period.

\section{Pre-Pottery Neolithic assemblage at İnanl Te- pe}

Architectural elements. The remains of three wellpreserved circular structures were found in the area southeast of the site. The diameter of the structures varies from 2 to $2.5 \mathrm{~m}$. All three structures are formed by arranging the flat sides of the shaped stone slabs in a horizontal form (Fig. 8). Similar structures were identified at Hamzan Tepe (Çelik 2010.259, Fig. 3-4). Other circular structures in the region from the same period are known from settlements at Çayönü (Erim-Özdoğan 2011.191-193, Fig. 6, 9), Hallan Çemi (Rosenberg 2011.61-63, Figs. 2-6), Hasankeyf Höyük (Miyake 2013.40, 43, 46, 47), Gusir Höyük (Karul 2011.2-4, Figs. 4-5, 11) and Körtik Tepe (Sicker-Akman 2001.389-394; Özkaya, Coskun 2011.90-93, Figs. 2-5). Moreover, the dimensions of the circular structures at Inanlı Tepe are similar to two structures with terrazzo flooring discovered at Sanliurfa-Yeni Mahalle (Celik 2007.162, Fig. 16; 2011a. 142, Fig. 15-16).

Small finds. Lithics dating to the Pre-Pottery Neolithic period were found during the field survey at the site. The assembladge is comprised of blades, flakes and flint by-products. The flint is mostly dark grey, light and dark brown. The flint tools consist of arrowheads, a scraper and silica flakes (Fig. 9.1-6). Rare flakes of obsidian are also present at İnanlı Tepe.

The circular structures discovered at İnanlı Tepe, pieces of Byblos and Nemrik arrowheads made of flint stone discovered on the surface, and unavailability of any Çayönü tools and Palmyra points most probably indicate that the settlement should be dated to the early PPNB period.

\section{The Neolithic of the Viranşehir region}

Viranşehir is a borough of the Şanliurfa province, located in the eastern part of the province. The mountain of Karacadağ is located on the northeast border of the region and is dominated by basaltic rocks in the north and calcareous rocks in the south and south-west. The southern and south-western areas are in the form of plains and low plateaus.

Areas with water sources cover large parts of this region, similarly to the Siverek region in this province. The Assağı Curcip and Yukarı Circıp streams rising from Karacadağ and flowing north-south to the Habur stream are the most significant water sources in the region. There is also a large number of springs on the southern side of Karacadağ and in the northern parts of the region. In spring the drought starts in the Viranşehir region which encompasses broad fields serving as pasture land.

The Sefer Tepe (Yukarı Darik Harabesi) site, which dates to the Pre-Pottery Neolithic period, was discovered during inventory studies in $2003^{3}$. The Başaran Höyük, Herzo Tepe, and Kocanizam Pre-Pottery Neolithic period sites (Map 1) were discovered during the study4 in 2011 (Güler et al. 2012.169-191).

\section{Başaran Höyük}

Başaran Höyük is located inside the Başaran village, $62 \mathrm{~km}$ east of Urfa and $26 \mathrm{~km}$ southwest of Viranșehir (Map 1). Sefer Tepe (Celik 2006a.23-25), discovered in 2003 , is located at $652 \mathrm{~m}$ altitude above sea level and $5 \mathrm{~km}$ south of the settlement at Başaran Höyük. The mound is elevated and conical, and located on a calcareous hill; the village cemetery which is currently in use covers a part of the mound (Fig. 10). The mound soil is $c .10 \mathrm{~m}$ high, measured from the bedrock. The mound covers an area of $c .20000 \mathrm{~m}^{2}$. The geological structure of the region is formed by calcareous plateaus. A stream bed is located to the $5.5 \mathrm{~km}$ north of the site. The closest source of basalt is $c .6 \mathrm{~km}$ north and the area is used primarily as pasture land.

The flint artefacts discovered at Başaran Höyük site are not concentrated throughout the entire area; the

\footnotetext{
3 Project for Social and Cultural History of Turkey, Project for Inventory of the Cultural Assets in Eastern and Southeastern Anatolia Regions.

4 These studies were conducted under the scope of TÜBITAK project entitled 'Determination, Inventory and Assessment of the Immovable Cultural Assets in Şanlıurfa Province and Districts of the Province.' We hereby present our acknowledgements to Mr. Celalettin Güvenç, the Governor of Sanlıurfa, Mr. Muhammed Lütfi Kotan, the District Governor of Viranșehir.
} 
number of flint tools discovered is 3 per $\mathrm{m}^{2}$ area. The site was inhabited as a settlement during the Pre-Pottery Neolithic period as presented by the flint tools. However, it is difficult to estimate the actual size of the settlement during the PPN period, since the site was covered with remains of younger cultural periods.

\section{Pre-Pottery Neolithic assemblage in Başaran Höyük}

Architectural elements. No architectural elements were discovered at Başaran Höyük. The cultural levels from the Bronze Age, Iron Age and Byzantium period are probably compacted with the PPN levels. However, cut-outs in groups with diameters varying from $c .10-15 \mathrm{~cm}$ in length and depths of $10 \mathrm{~cm}$ were discovered in the rock floor where the mound cone ends (Fig. 11). These cut-outs chiselled in the bedrock have features identical to those at Göbekli Tepe, Hamzan Tepe, and Karahan Tepe (Beile-Bohn et al. 1998.47-50, Abb. 20; Hauptmann 1999.Fig. 32; Colik 2000b. 7; 2004.3, Figs. 2-3; 2006b.222, Figs. 34; 2010.259, Fig. 6; 2011b.259, Figs. 18-21).

Small finds. During the studies conducted at $\mathrm{Ba}$ şaran Höyük, pottery from the Bronze Age, Iron Age and Byzantine periods was discovered in addition to the Pre-Pottery Neolithic finds. The flint tools are comprised of flint blades, flakes and by-products. The flint is mainly light and dark brown, beige and grey. Arrowheads, scrapers, piercing tools and crested blade pieces from this period were discovered (Fig. 12.1-9). Also rare obsidian blade pieces were found at the site (Fig. 12.10).

The arrowheads discovered at Başaran Höyük are very similar to the arrowheads discovered at Karahan Tepe and Sefer Tepe both in terms of their size and form (Celik 2006a.24, Fig. 4 b-d; 2011.244245, Figs. 18.4-9, 19.1-8). This type of small arrowheads were also found at Nemrik (Koztowski, Szymczak 1989.32, Fig. 2; Abbes 1993.Fig. 8.10; Cauvin 1994.Fig. 24.1, 3; Schmidt 2001.52, Fig. 10.4, 6) and Byblos (Schmidt 1988.171-174, Abb. 11.1-6, 12.1-3; Cauvin 1994.Fig. 26.3) and are dated to the early PPNB period (Cauvin 1994.78-79, Fig. 24.2).

The presence of cut-out groups chiselled on the bedrock surrounding the mound and used for pool construction technique, as well as the Nemrik and Byblos arrowheads indicates that Başaran Höyük was probably occupied at the end of the late PPNA and in the early PPNB period.

\section{Herzo Tepe}

Herzo Tepe is located $62 \mathrm{~km}$ east of Urfa and $3.5 \mathrm{~km}$ south of Sefer Tepe (Map 1) and is $574 \mathrm{~m}$ above sea level. The geology of the region is formed by calcareous plateaus. Founded on a calcareous hill, the mound is a low and ample structure (Fig. 13). The mound soil is $c .3 \mathrm{~m}$ above the bedrock and covers an area of $c .10000 \mathrm{~m}^{2}$. The closest water source is $4 \mathrm{~km}$ north of the site. The closest basalt source, on the other hand, is $c .4 .5 \mathrm{~km}$ north of the site. A large area of the settlement was destroyed due to the construction of rock-cut tombs in the early Byzantine period and modern agricultural activity.

The flint tools at Herzo Tepe site were discovered throughout the entire area, with a density of $c .20$ per $\mathrm{m}^{2}$. As a result of the examinations of the flint tools, it is understood that The site was inhabited as a settlement during the Pre-Pottery Neolithic period.

Pre-Pottery Neolithic assemblage at Herzo Tepe Architectural elements. The remains of a circular building were encountered east of the settlement (Fig. 14), with an approximate diameter of $5 \mathrm{~m}$. The closest example of this structure is known from Hamzan Tepe (Celik 2004.3-5; 2010.259, Figs. 3-4). Moreover, the diameter of the structure is identical with structures discovered at Hasankeyf Höyük ( $M i$ yake 2013.40, 43, 46, 47). Other similar structures are known in settlements at Çayönü (Erim-Özdoğan 2011.191-193, Figs. 6, 9), Hallan Çemi (Rosenberg 2011.61-63, Figs. 2-6), Hasankeyf Höyük (Miyake 2013.40, 43, 46, 47), Gusir Höyük (Karul 2011.2-4, Figs. 4-5, 11) and Körtik Tepe (Özkaya, Coşkun 2011.90-93, Figs. 2-5).

Small finds. The field survey revealed pottery from the early Byzantine period, as well as hand-made straw-tempered ceramic pieces and lithics from the Pre-Pottery Neolithic period. Flint tools are comprised of flint blades, flakes, production waste, unipolar and bipolar cores. The flint is principally light and dark brown, beige and grey. Arrowheads, scrapers, piercing tools, crested blades and blades with a silica sheen were discovered from this period (Fig. 15.1$4,6,7)$. In addition, rare obsidian blade pieces were also found (Fig. 15.5). The tools include small Nemrik arrowheads (Fig. 15.9-13) and one Byblos type arrowhead (Fig. 15.8). Basalt grind stones and pestle pieces were also found.

The circular building at Herzo Tepe and the Nemrik type arrowheads found in the surface survey indi- 
cate that the site dates to the end of the PNA period and early PPNB period.

\section{Kocanizan Tepe}

Kocanizam Tepe is $c .653 \mathrm{~m}$ above sea level and located in the Kocanizam village, $60 \mathrm{~km}$ east of Urfa, $25 \mathrm{~km}$ west of Viransehir and $3 \mathrm{~km}$ north of Sefer Tepe (Map 1). The region is formed by calcareous plateaus. Founded on a calcareous hill, the mound is low and ample (Fig. 16). The height of the mound soil is around $6 \mathrm{~m}$ above the bedrock. Kocanizam Tepe covers a surface area of $c .15000 \mathrm{~m}^{2}$. The closest water source is $1.5 \mathrm{~km}$ east of the settlement. The closest basalt source is $c .1 \mathrm{~km}$ to the east of the site. A significant portion of the site was destroyed by later construction in the early Byzantine period.

The flint tools discovered at Kocanizam Tepe were spread over the entire area at a density of around 10 per $\mathrm{m}^{2}$. As a result of the examinations of the flint tools discovered at the site, the site is dated to the Pre-Pottery Neolithic period.

\section{Pre-Pottery Neolithic assemblage at Kocani- zam Tepe}

Architectural elements. A calcareous stone believed to be the body of a T-shaped pillar was unearthed in an illegal excavation site at the centre of the settlement area. The stone is flat and chiselled into rectangular shape, with both short edges broken (Fig. 17).

Small finds. During the field survey, pottery and architectural remains from the early Byzantine period were discovered, as well as blades, flakes and waste production made of flint stone and unipolar and bipolar cores that could be dated to the Pre-Pottery Neolithic period (Fig. 18.1-2). The flint is light and dark brown, beige and gray in colour. The most significant lithic artefacts are the Nemrik type arrowheads, scrapers, crested blades and blades with silica sheen (Fig. 18.4-5, 8-11). Furthermore, blade pieces made of obsidian are also encountered (Fig. 18. 6-7) as well as grinding stones and pestle pieces made of basalt.

The Neolithic settlement located inside Kocanizam village should be dated to the end of the PPNA period (LPPNA) and early PPNB period (EPPNB) according to the Nemrik arrowheads discovered at the site and the presence of calcareous stone estimated to be a part of a T-shaped pillar.

\section{Sefer Tepe (Yukarı Darik Harabesi)}

Sefer Tepe is a small, broad and shallow mound (Fig. 19) located $c .72 \mathrm{~km}$ east of Sanliurfa, within the modern province borders of Viranșehir (Map 1). The mound is located at $600 \mathrm{~m}$ altitude above sea level and covers a surface area of $c .7000 \mathrm{~m}^{2}$. A country house is located in the south-eastern corner of the site. The closest water source is Yukarı Circip creek, $1.5 \mathrm{~km}$ to the east. The geological foundation is of calcareous rock and the closest basalt source is located $1 \mathrm{~km}$ to the east.

\section{Pre-Pottery Neolithic Assemblage at Sefer Tepe (Yukari Darik Harabesi)}

Architectural elements. The most intriguing aspect of the Sefer Tepe site are the 16 in-situ T-shaped pillars (Kürkçüoğlu, Karahan Kara 2005.62-63; Celik 2006a.23-25). Most of the pillars were buried and placed side-by-side in a conjugate formation at c. 1.5 up to $2 \mathrm{~m}$ intervals (Fig. 20). The upper sections above the surface are $c .50 \mathrm{~cm}$ long and $20 \mathrm{~cm}$ wide. The positioning of the pillars is very similar to the architecture at Göbekli Tepe Level II (Schmidt 2002. 8, Fig. 7) 5 and the monolithic in-situ pillars on the surface at Karahan Tepe (Celik 2000b.6-7; 2011. 241-242, Fig. 7). Moreover, another pillar was revealed during the construction of the country house in the south-eastern corner of the site. This pillar was found intact (Fig. 21); its length is $198 \mathrm{~cm}$ and the width of the head section is $72 \mathrm{~cm}$, the width of the body section $54 \mathrm{~cm}$ and the thickness $25 \mathrm{~cm}$. The head section of this undecorated stele is extremely flattened; it has features identical with the pillars discovered at Nevali Cori, Göbekli Tepe, Karahan Tepe, Hamzan Tepe and Taşlı Tepe.

Small finds. Only flint and obsidian tools were discovered at Sefer Tepe. The proportion of obsidian to flint tools is 1:7. Arrowheads, piercing tools, end scrapers and blades with a silica sheen were among the lithic artefacts. On the other hand, only one scraper piece and blade pieces were identified among the obsidian tools. Typologically, tools dating to the PrePottery Neolithic were identified among the flint stone finds (Fig. 22.1-6). The flint arrowheads in particular are of the Byblos type with some unidentified types (Celik 2006a.25, Fig. 4), where only the distal and proximal sections are well-preserved (Fig. 22.45). Identical arrowheads were found at Göbekli Tepe (Beile-Bohn et al. 1998.Abb. 23.3; Schmidt 2001.52, Figs. 10/3, 11/5), Nevali Çori (Schmidt 1988.Abb.

5 Locations of the pillars at L10-71, L9-80, L9-55 and L9-56 trenches. 
8.5), Şanlurfa-Yeni Mahalle (Celik 2000a. Fig. 5.2) and Karahan Tepe (Celik 2000b.Fig. 4a). Moreover, one piece of a stone pot, similar to the ones discovered at Körtik Tepe (Özkaya, Coskun 2011.90-93, Figs. 15-21, 26), was used as whetstone (Fig. 22.6).

The Viranşehir Plain extends to the north and east of Sefer Tepe; the site is located $c .20 \mathrm{~km}$ from Karahan Tepe, $28 \mathrm{~km}$ from Taşlı Tepe, $50 \mathrm{~km}$ from Göbekli Tepe and $63 \mathrm{~km}$ from Şanlıurfa-Yeni Mahalle and Hamzan Tepe ${ }^{6}$. The Sefer Tepe site dates to the early PPNB as it has features identical to Level II of Göbekli Tepe.

\section{Concluding remarks}

Circular structures were not discovered during the excavations of the Urfa region, except at Hamzan Tepe and Yeni Mahalle discovered in previous studies. We are used to observing such Early PPNB structures in the catchment area of the Tigris River. The circular structures here, on the other hand, are generally from the PPNA period that has different construction materials. The walls discovered at Hamzan Tepe, Herzo Tepe and İnanlı Tepe were built with large, partially dressed stone. The walls of the structures in the catchment area of the Tigris River, however, were built with small rubble. The flint tools from the surface at Herzo Tepe and İnanlı Tepe, that include circular structures, show that these sites date to the early PPNB period.

The cult/ritual structures recognised at Göbekli Tepe and Nevali Çori include T-shaped pillars with and without reliefs and statues. We acquired plenty of information on this type of buildings from the excavations at Göbekli Tepe. In particular, Level II, dated to the Early PPNB and contemporaneous with the cult structure at Nevali Çori, and Level III, dated to the PPNA period, offer new information on these cult structures. Thus far, no sites or cult centres from the PPNA period, which is contemporaneous with Level III of Göbekli Tepe, have been found.

All the new sites discovered in the Siverek and Viranşehir region are dated to the early PPNB period. Such dating is proven particularly by the resemblance of the pillars discovered at Tasslı Tepe and Sefer Tepe, characterised as cult centres, with pillars similar to Göbekli Tepe Level II in terms of dimensions. The same feature is also found in pillars in the cult structure at Nevali Cori Level III. The pillars here also date to the Early PPNB.
The most significant feature of Taşlı Tepe is the fact that it is the only example occupied in a single period, the Pre-Pottery Neolithic. Unfortunately, the architectural elements found on the surface were removed during levelling works by farming activities on the hill. Tassli Tepe is characterised as a cult centre with T-shaped pillars. The contemporaneous sites are the Pre-Pottery Neolithic Sefer Tepe, $28 \mathrm{~km}$ to the southeast, Karahan Tepe, $30 \mathrm{~km}$ south, and Göbekli Tepe, $35 \mathrm{~km}$ to the west. The fact that the distance between Tasslı Tepe and Sefer Tepe, Karahan Tepe and Göbekli Tepe is approximately identical indicates that the distance between the sites where Tshaped pillars are present was arranged to a certain pre-planned layout. The sites in the region are generally founded either on or immediately beside high plateaus (Özdoğan 2011.229). This fact might be used to designate the borders between the sites. Therefore, Taşlı Tepe is considered a site characterised by T-shaped pillars, such as Göbekli Tepe, Nevali Çori, Karahan Tepe, Sefer Tepe and Hamzan Tepe. The fact, that the number of sites increases gradually, means that they not only comprise cult centres in this period, but that they are also independent cult structures within the settlements as can be seen at Nevali Çori.

The absence of T-shaped pillars at Herzo Tepe and Inanlı Tepe and the presence of circular structures indicate that this type of sites were settlements not cult or ritual centres. The distances between Başaran Höyük, Herzo Tepe, Kocanizam Tepe and Sefer Tepe vary from 2 to $8 \mathrm{~km}$. Moreover, all four sites are aligned in a north-south direction. Sefer Tepe, which has T-shaped pillars, is located at the centre of the other four sites; the distance to the other settlements varies from 3 to $5 \mathrm{~km}$. This arrangement might indicate that Sefer Tepe was a cult centre for the other settlements. It is of particular importance with respect to presenting territorial areas in the region in the Pre-Pottery Neolithic period. This fact also suggests a settlement type we encountered at other PPN sites in the region.

Sites dating to the early periods of the Pre-Pottery Neolithic period were generally founded on, or on the hillside of, high plateaus in the region. Likewise, Başaran Höyük, Herzo Tepe and Kocanizam Tepe were founded on high plateaus and down bedrock. This type of settlement tradition is also seen at the Sefer Tepe, Taşlı Tepe, Karahan Tepe, Göbekli Tepe, Şanliurfa-Yeni Mahalle and Hamzan Tepe Pre-Pottery Neolithic sites in the region. 
The presence of circular structures constructed at Herzo Tepe and Hamzan Tepe settlements is important, as it demonstrates that two distinct architectural traditions were present in the region during the Pre-Pottery Neolithic period. The presence of sites characterised as cult or ritual centres, such as Göbekli Tepe, Karahan Tepe, Taşlı Tepe and Sefer Tepe, suggests that other settlements must have been present in the region. In the future, it might be possible to find other cult or ritual centres, settlements, or a combination of the two types in the region with systematic studies and excavations.

The absence of Palmyra points and Cayönü tools at Taşlı Tepe, İnanlı Tepe, Başaran Höyük, Herzo Tepe,
Kocanizam Tepe and Sefer Tepe, and the fact that these sites have features similar to those in Level II at Göbekli Tepe and Level III of Nevali Çori, enable us to date such sites to the early PPNB.

\section{ACKNOWLEDGEMENTS}

The studies mentioned in the paper are being conducted within the TUBITAK project 'Determination, Inventory and Assessement of Immovable Cultural Assets in Sanhurfa Province and Boroughs'. We would like to thank Mr. Nuri Okutan, the Governor of Sanlurfa during the period concerned, and Mr. Mahmut Hersanhoğlu, District Governor of Siverek.

\section{References}

Abbes F. 1993. Methode d'approce de la variabilite du debitage laminaire, application a des armatures percantes de Cheikh Hassan (syrie. VIIIe millenaire B.C.). Cahiers de I'Euphrate 7: 119-150.

Beile-Bohn M., Gerber C., Morsch M. and Schmidt K. 1998. Frühneolithische Forschungen in Obermesopotamien. Göbekli Tepe und Gürcütepe. Istanbuler Mitteilungen 48 : 5-78.

Cauvin J. 1994. Naissance des divinites, naissance de l'agriculture. La revolution des symboles au Neolithique. Editions CNRS. Paris.

Çelik B. 2000a. A New Early Neolithic Settlement in the Center of Sanlıurfa, Turkey. Neo-Lithics 2(2-3): 4-6.

2000b. A New Early-Neolithic Settlement: Karahan Tepe. Neo-Lithics 2(3): 6-8.

2004. A New Early-Neolithic Settlement: Hamzan Tepe. Neo-Lithics 2(4): 3-5.

2006a. A New Early Neolithic Settlement in Southeastern Turkey: Sefer Tepe. Neo-Lithics 6(1): 23-25. 2006b. A New Lower Paleolithic Open Air Station and Early Neolithic Settlement. In Hayat Erkanal'a Armagan, Kültürlerin Yansimasi/Studies in Honor of Hayat Erkanal, Cultural Reflections. Homer Kitapçıllk ve Yayınevi Ltd. Şti. Istanbul: 222-224.

2007. Sanlıurfa-Yeni Mahalle Balıklıgol Höyüğü. In M. Özdoğan, N. Başgelen (eds.), Anadolu'da Uygarligın Dogusu ve Avrupa'ya Yaynlımı, Turkiye'de Neolitik
Donem, Yeni Kazılar, Yeni Bulgular. Arkeoloji ve Sanat Yayınları. Istanbul: 165-178.

2010. Hamzan Tepe in the Light of New Finds. Documenta Praehistorica 37: 257-268.

2011a. Şanlıurfa-Yeni Mahalle. In M. Özdoğan, N. Başgelen and P. Kuniholm (eds.), The Neolithic in Turkey. New Excavation \& New Research. The Euphrates Basin. Archaeology \& Art Publications. Istanbul: 139-164.

2011b. Karahan Tepe: A New Cultural Centre in Urfa Area in Turkey. Documenta Praehistorica 38: 241253.

Çelik B., Güler M. and Güler G. 2011. Türkiye'nin Güneydoğusunda Yeni Bir Çanak Çömleksiz Neolitik Yerleşim: Taşlı Tepe/A New Pre-Pottery Neolithic Settlement in Southeastern Turkey: Taşlı Tepe. Anadolu/Anatolia 37: 225-236.

Erim-Özdoğan A. 2011. Çayönü. In M. Özdoğan, N. Başgelen and P. Kuniholm (eds.), The Neolithic in Turkey. New Excavation \& New Research. The Tigris Basin. Archaeology \& Art Publications. Istanbul: 185-269.

Güler M., Çelik B. and Güler G. 2012. Viranşehir İlçesinden Yeni Pre-Pottery Neolithic period Yerleşimleri. Anadolu/Anatolia 38: 169-191.

Hauptmann H. 1991/1992. Eine Siedlung des akeramischen Neolithikums am mittleren Euphrat. Nürnberger Blätter zur Archäologie 8: 15-33. 
1999. The Urfa Region. In M. Özdoğan, N. Başgelen (eds.), Neolithic in Turkey, the cradle of civilization. New Discoveries. Arkeoloji ve Sanat Yayınları. Istanbul: $65-86$.

2007. Nevali Çori ve Urfa Bölgesinde Neolitik Dönem. In M. Özdoğan, N. Başgelen (eds.), Anadolu'da Uygarlı̆̆n Doğuşu ve Avrupa'ya Yayılım, Türkiye'de Neolitik Dönem, Yeni Kazular, Yeni Bulgular. Arkeoloji ve Sanat Yayınları. Istanbul: 131-164.

Karul N. 2011. Gusir Höyük. In M. Özdoğan, N. Başgelen and P. Kuniholm (eds.), The Neolithic in Turkey. New Excavation \& New Research. The Tigris Basin. Archaeology \& Art Publications. Istanbul: 1-17.

Kozłowski S. K., Szcymczak K. 1989. Flint Industry from House $1 / 1 \mathrm{~A} / 1 \mathrm{~B}$ at the PPN Site in Nemrik 9, Northern Iraq. Paléorient 15(1): 32-42.

Kürkçüoğlu A. C., Karahan Kara Z. 2005. Adım Adım Viranşehir. Viranşehir Kaymakamlığ1 Kültür ve Turizm Yayınları. Yılmaz Ofset. Şanlıurfa.

Miyake Y. 2013 Dicle'nin İlk Köyü. Arkeoatlas 8: 40-47.

Özdoğan M. 2011. Anadolu İlk Neolitik Kültürlerinin Kökeni Sorunu. In H. Taşkıran, M. Kartal, K. Özçelik, M. B. Kösem and G. Kartal (eds.), Işın Yalçınkaya'ya Armağan Kitabı, Studies in Honor of Işın Yalçnkaya. Bilgin Kültür Sanat Yayınları. Ankara: 227-233.

Öztan A. 2012. Köşk Höyük. In M. Özdoğan, N. Başgelen and P. Kuniholm (eds.), The Neolithic in Turkey. New Excavation \& New Research. Central Turkey. Archaeology \& Art Publications. Istanbul: 31-70.

Özkaya V., Coşkun A. 2007. Körtik Tepe. In N. Başgelen (ed.), 12000 Yll Önce Uygarlı̆ı̆n Anadolu'dan Avrupa'- ya Yolculuğunun Başlangıcı Neolitik Dönem. Yapı Kredi Yayınlar1. Istanbul: 86-88.

2011. Körtik Tepe. In M. Özdoğan, N. Başgelen and P. Kuniholm (eds.), The Neolithic in Turkey. New Excavation \& New Research. The Tigris Basin. Archaeology \& Art Publications. Istanbul: 89-127.

Rosenberg M. 2011. Hallan Çemi. In M. Özdoğan, N. Başgelen and P. Kuniholm (eds.), The Neolithic in Turkey. New Excavation \& New Research. The Tigris Basin. Archaeology \& Art Publications. Istanbul: 1-78.

Schmidt K. 1988. Nevali Çori: Zum Typenspectrum der Silexindustrie und der Übrigen Kleinfunde. Anatolica 15: 161-201.

2001. Göbekli Tepe, Southeastern Turkey. A preliminary report on the 1995-1999 excavations. Paleorient 26(1): 45-54.

2002. The 2002 Excavations at Göbekli Tepe (Southeastern Turkey) - Imressions from an Enigmatic Site. Neo-Lithics 2(2): 8-13.

2007. Göbekli Tepe. In N. Başgelen (ed.), $12000 \mathrm{Y \imath l}$ Önce Uygarliğın Anadolu'dan Avrupa'ya Yolculuğunun Başlangıcı Neolitik Dönem. Yapı Kredi Yayınları. Istanbul: 93-95.

Sicker-Akman M. 2001. Die Rundhütte als Ursprung Zur Entwicklung erster runder Hütten zum geregelten Rechteckbau. In R. M. Boehmer, J. Maran (eds.), Lux orientis. Archäologie zwischen Asien und Europa. Festschrift für Harald Hauptmann zum 65. Geburtstag. Internationale Archäologie. Studia honoraria 12. Verlag Marie Leidorf. Rahden: 389-394. 


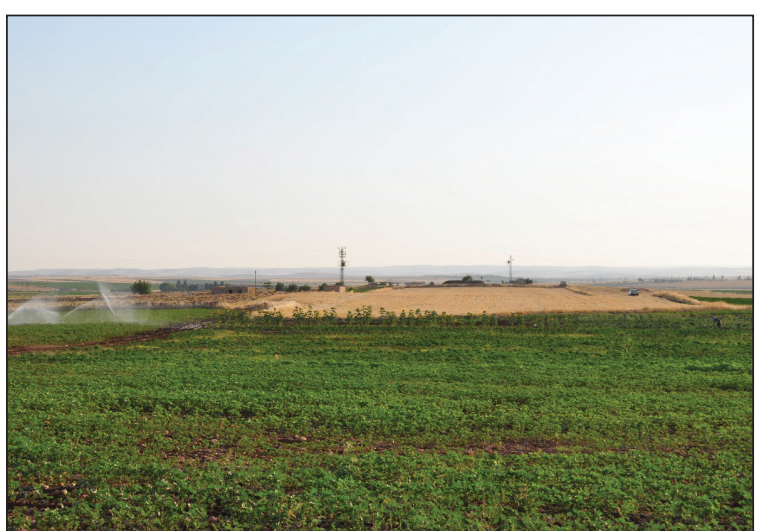

Fig. 1. Tassl Tepe from the east.

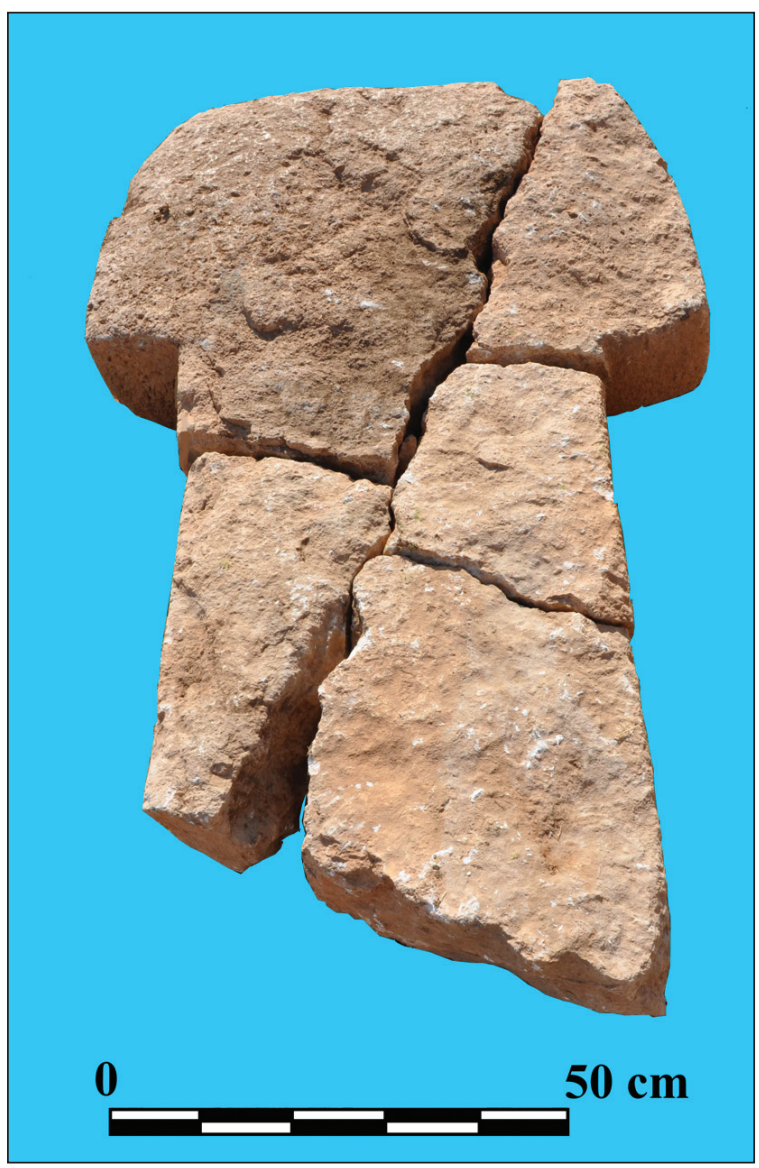

Fig. 2. T-shaped pillar; front view.

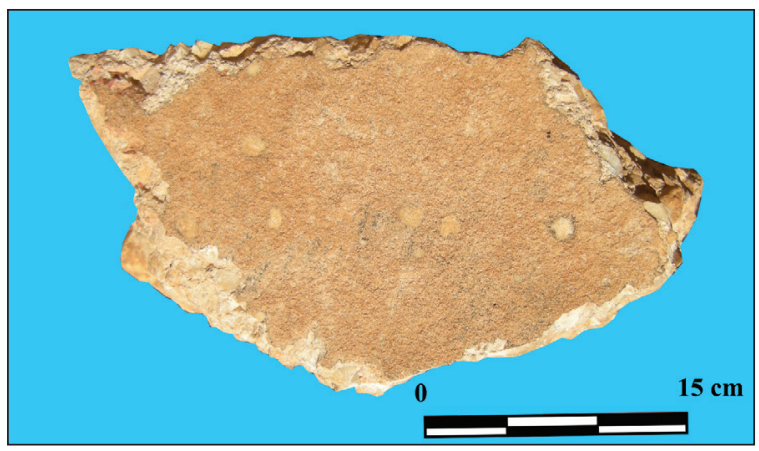

Fig. 3. Fragment of terrazzo floor.
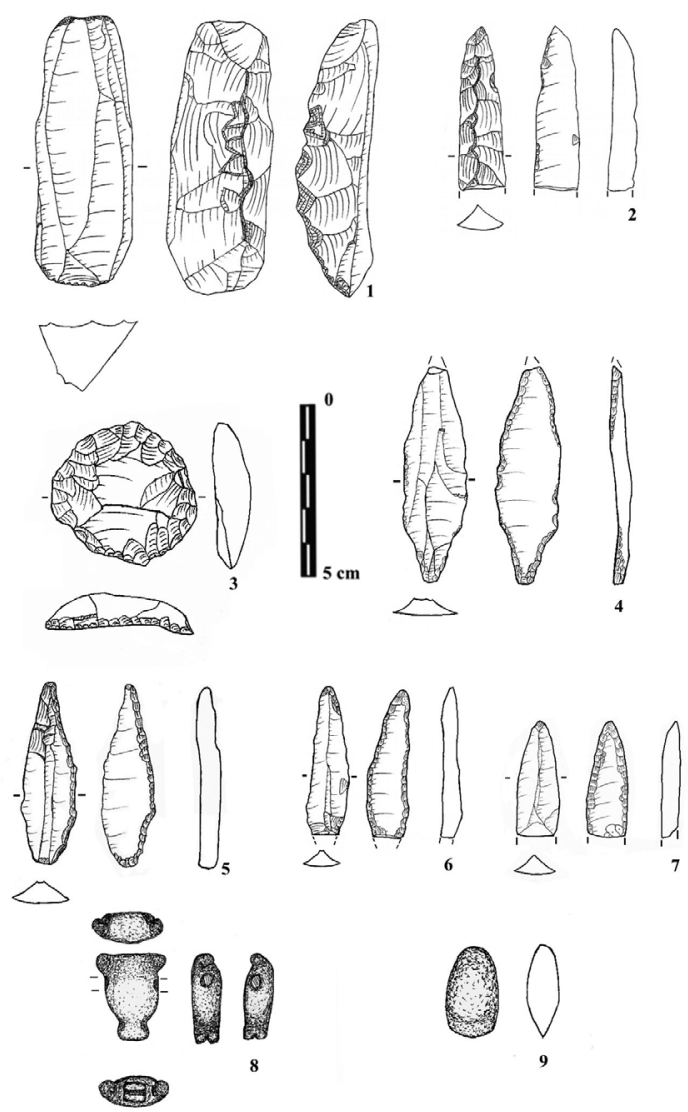

Fig. 4. Taşl Tepe Neolithic finds.

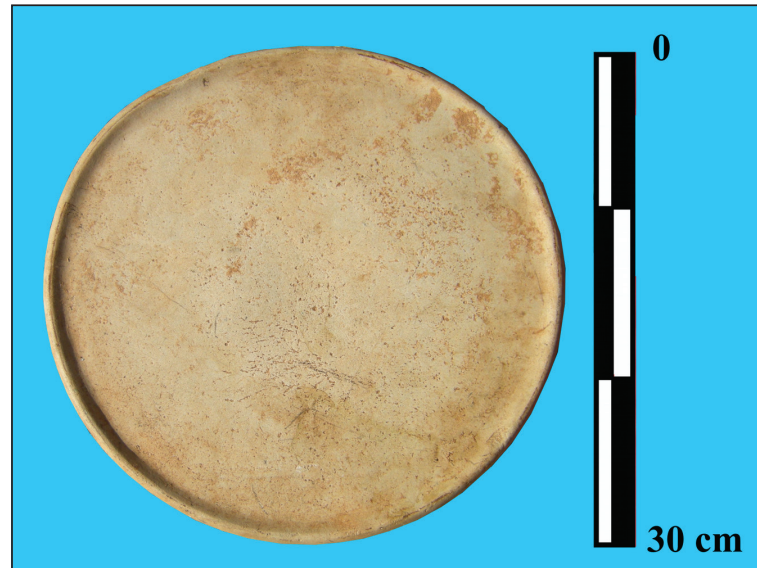

Fig. 5. Stone dish or plate.

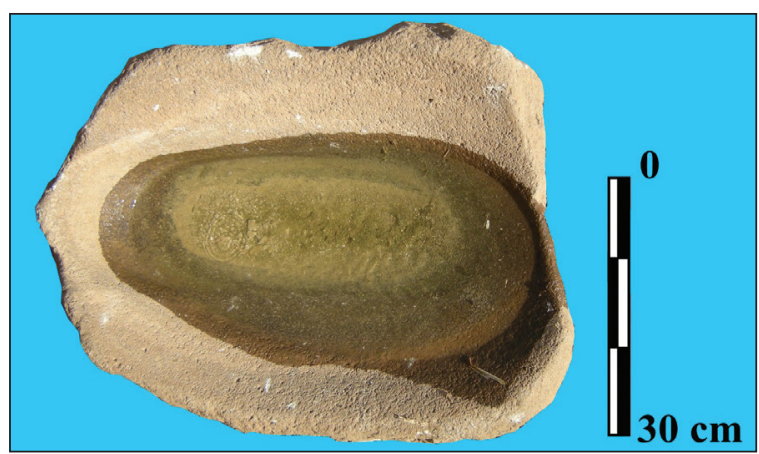

Fig. 6. Grind stone. 


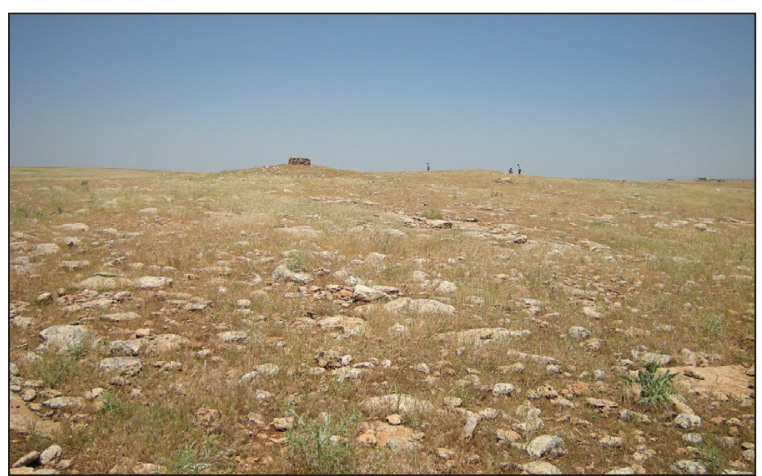

Fig. 7. Inanl Tepe from the south.

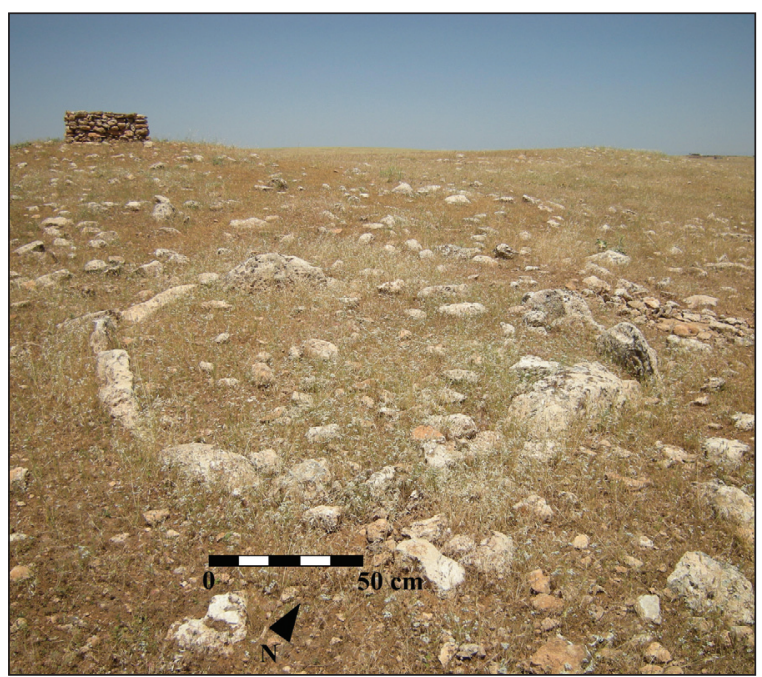

Fig. 8. Circular building at Inanlı Tepe.

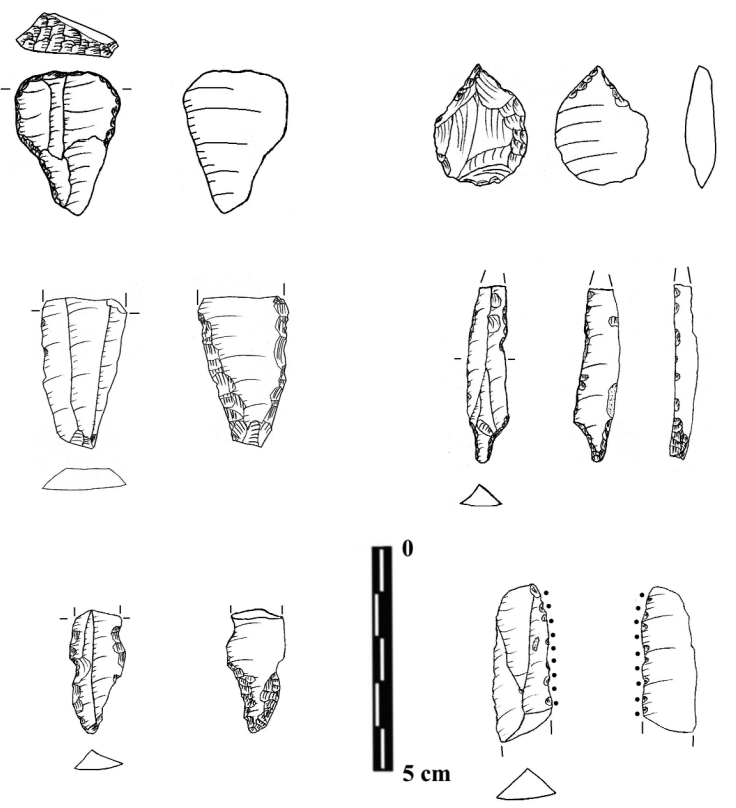

Fig. 9. Inanl Tepe lithic tools.

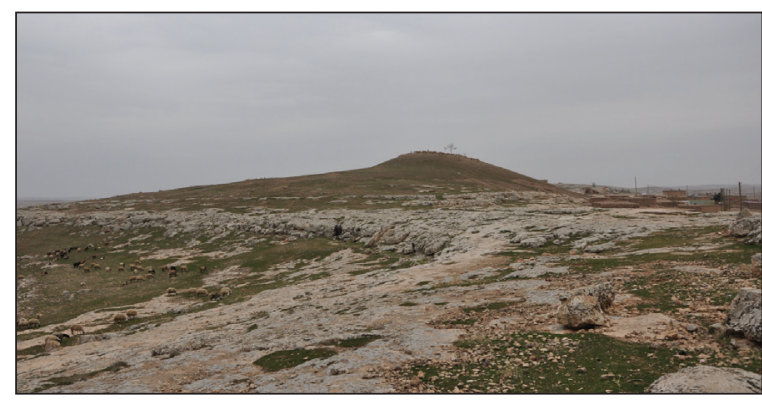

Fig. 10. Başaran Höyük from the east.

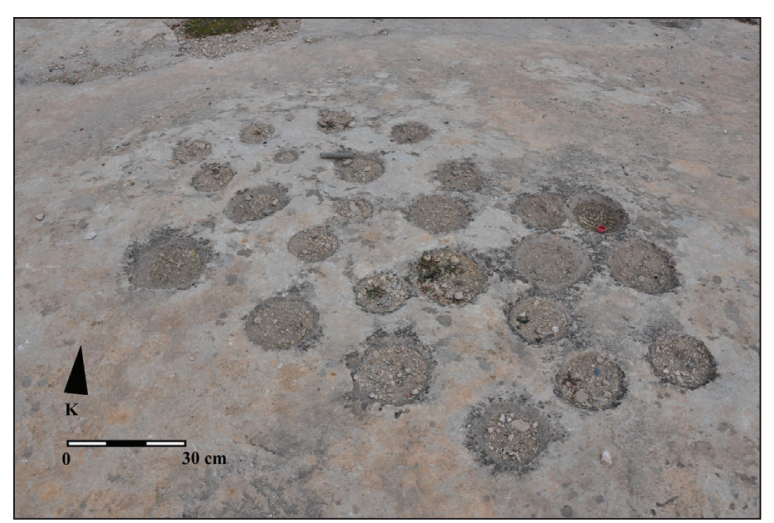

Fig. 11. Small cut-out groups cut into surrounding bedrock.
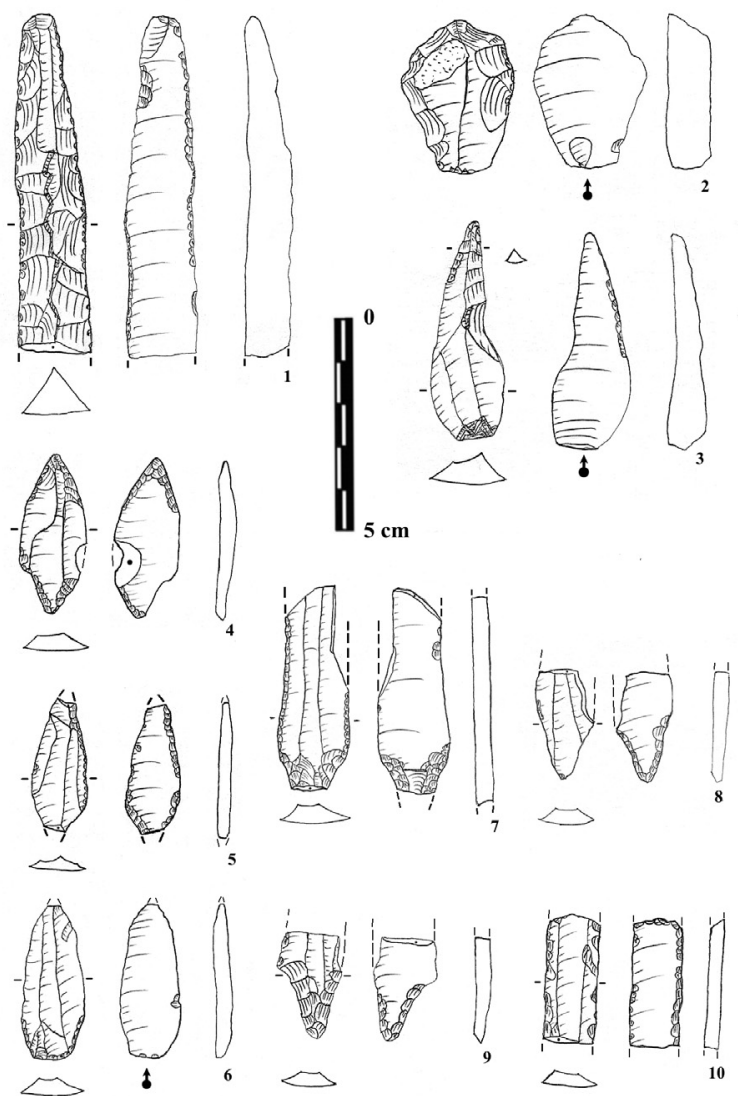

Fig. 12. Başaran Höyük Neolithic finds. 


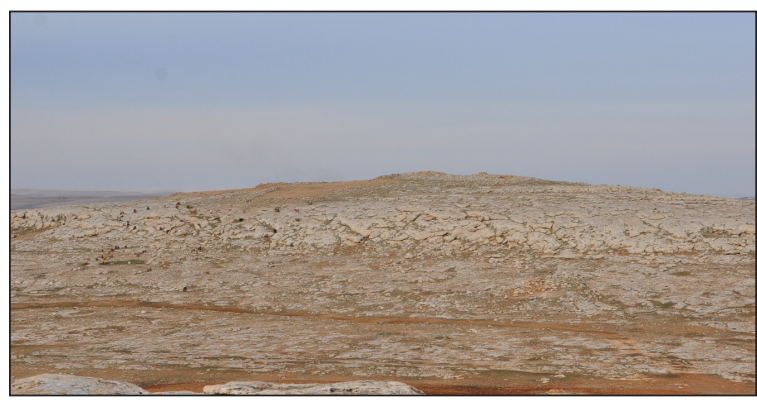

Fig. 13. Southwest view of Herzo Tepe.

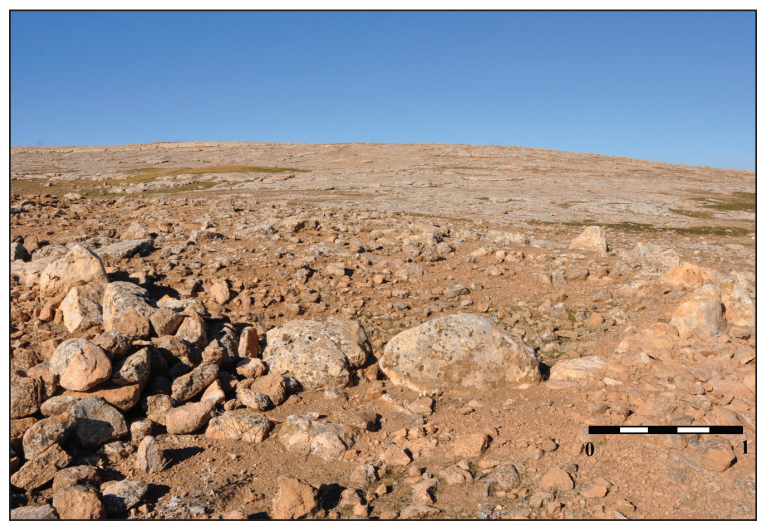

Fig. 14. Circular building at Herzo Tepe.
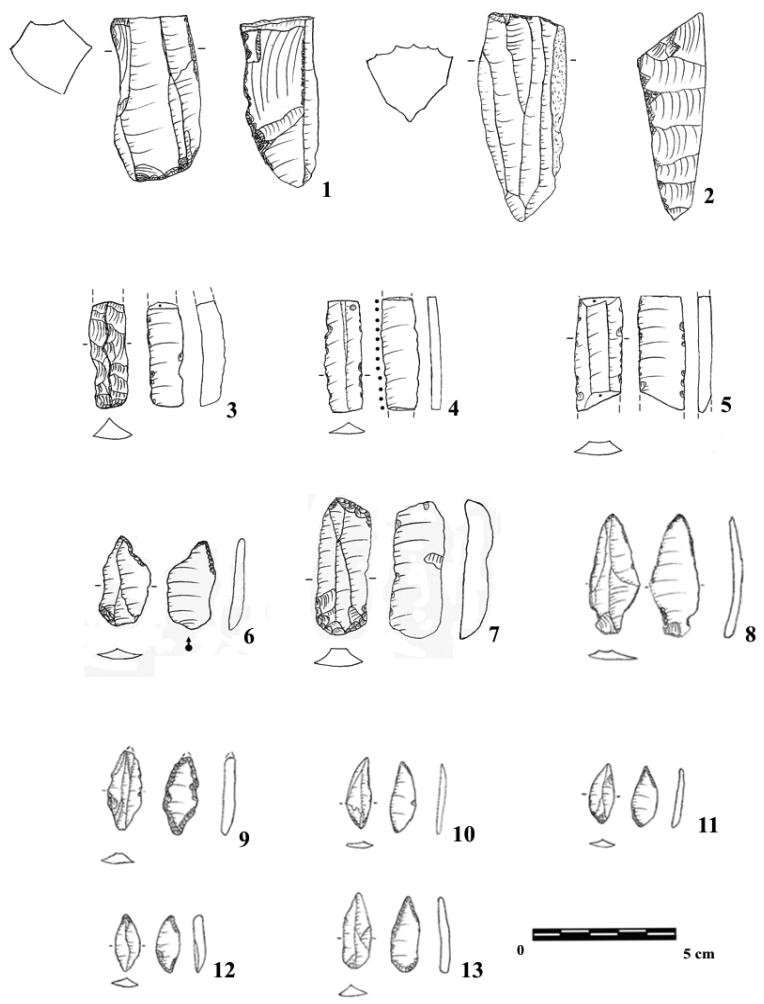

Fig. 15. Herzo Tepe Neolithic finds.

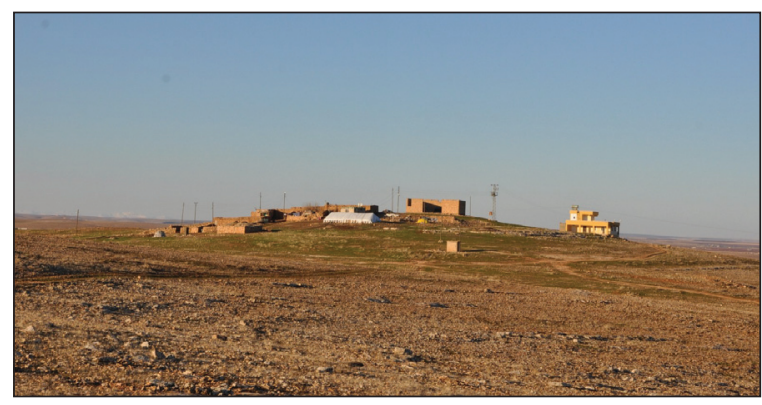

Fig. 16. Kocanizam from the south.

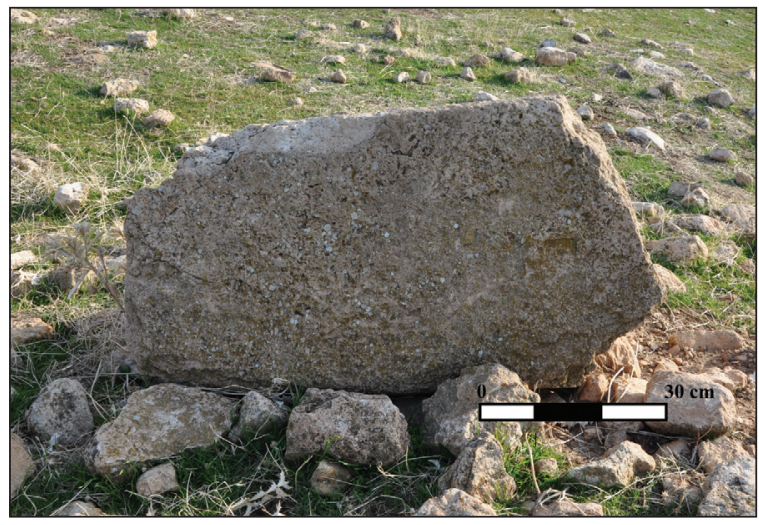

Fig. 17. Kocanizam Tepe piece of T-shaped pillar.
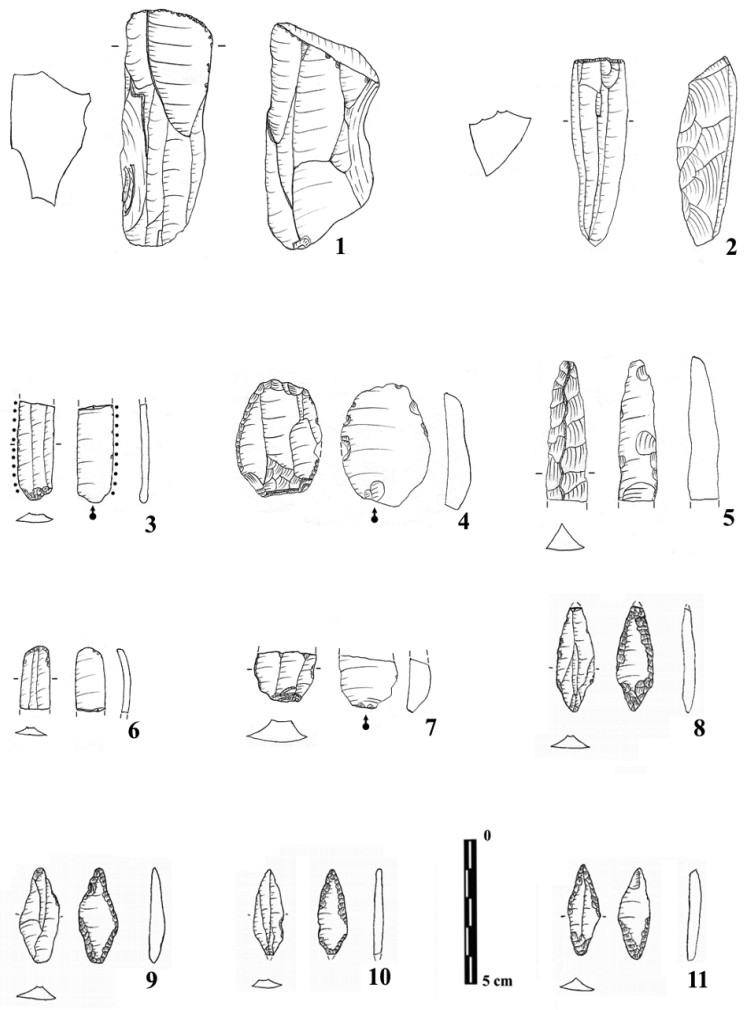

Fig. 18. Kocanizam Neolithic finds. 


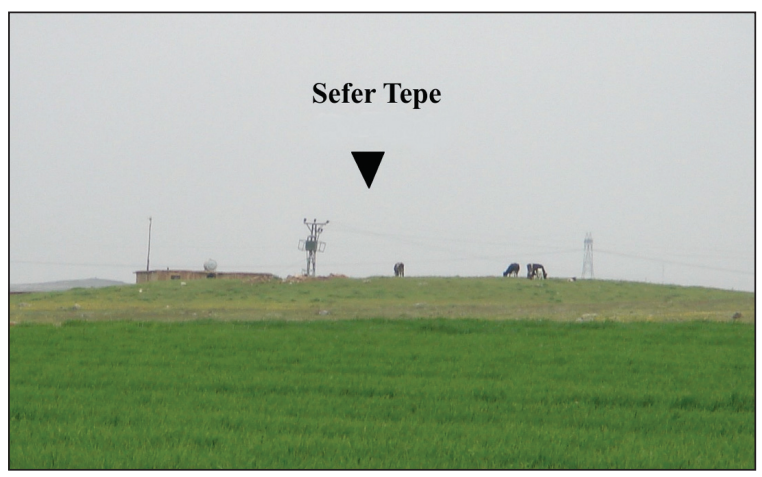

Fig. 19. Sefer Tepe from the north.

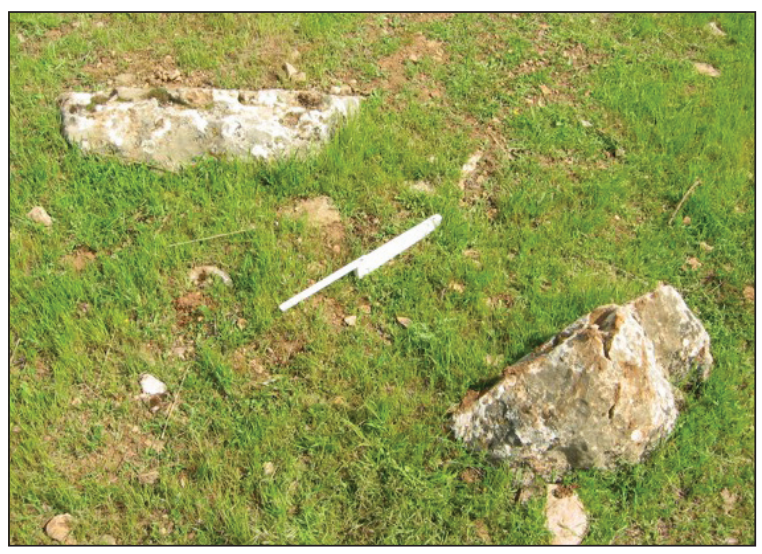

Fig. 20. Pillars at Sefer Tepe opposite each other.

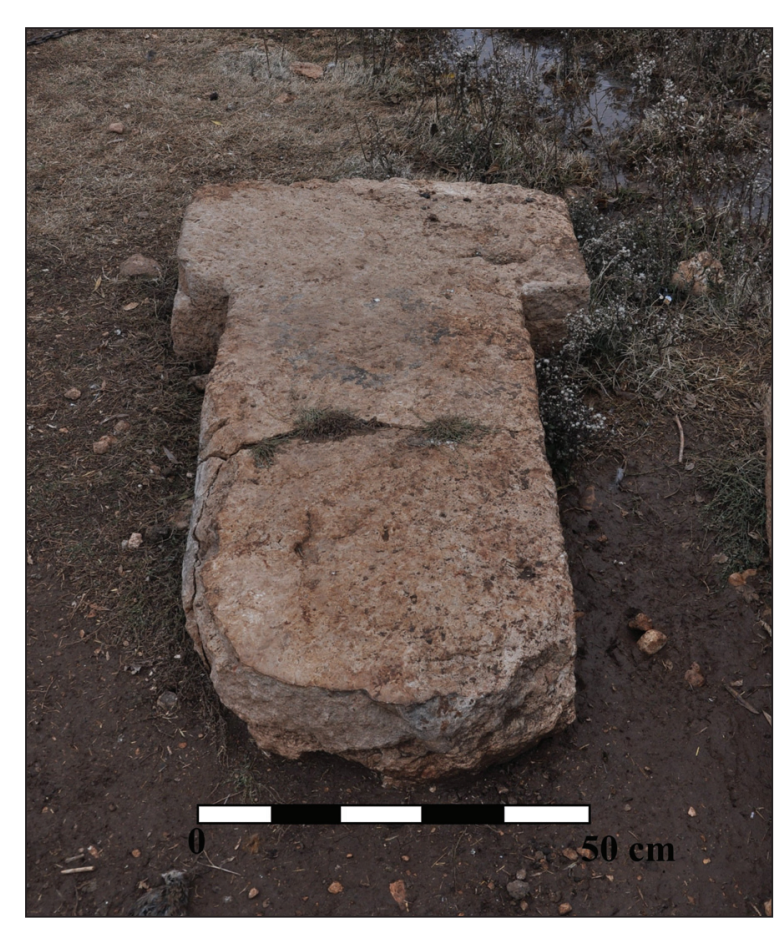

Fig. 21. T-shaped pillar; front view.
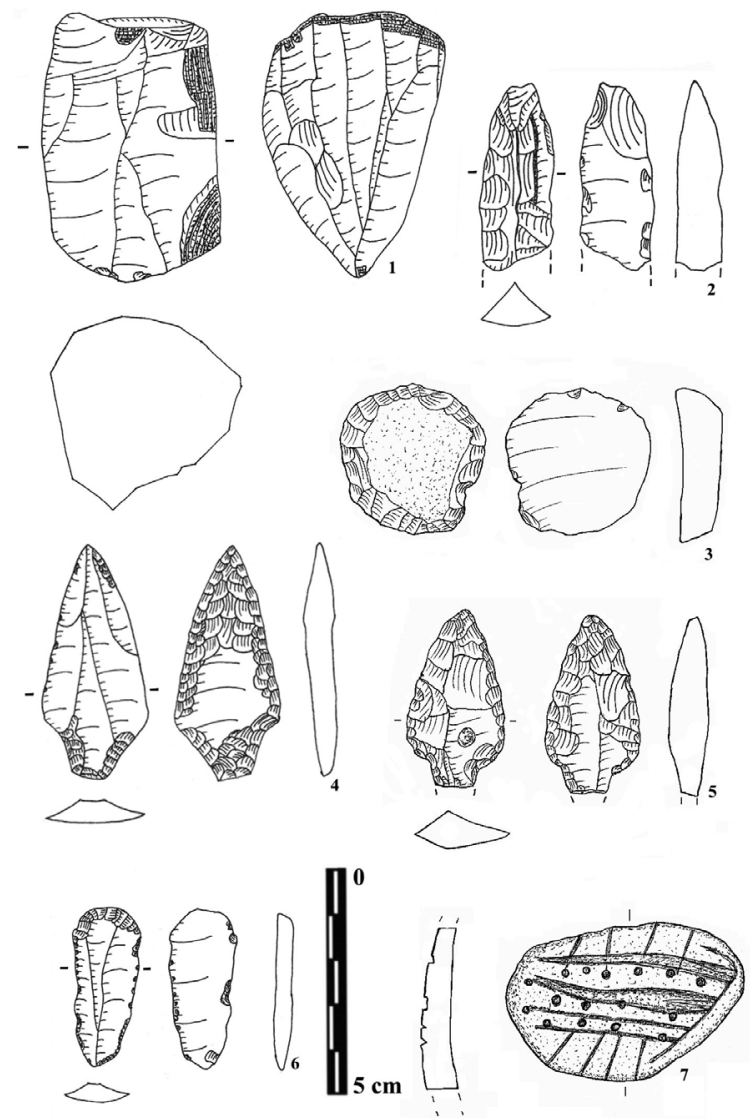

Fig. 22. Sefer Tepe Neolithic finds. 